\title{
Volleyball learning media using method of teaching games for understanding adobe flash-based
}

\author{
Refatana Asri Fani *, Pamuji Sukoco \\ Universitas Negeri Yogyakarta. Jalan Colombo No 1, Karangmalang, Yogyakarta, 55281, Indonesia \\ * Corresponding Author. E-mail: E-mail: refatana.fikuny@gmail.com
}

Received: 6 September 2018; Revised: 26 October 2019; Accepted: 20 December 2019

\begin{abstract}
The study aims at generating a product in the form of volleyball learning materials CD with the valid and effective TGFU method for the junior high school students. The learning media has been developed by using the Adobe Flash CS 6 Professional. Then, within the conduct of the study, the Research and Development (R\&D) Model proposed by Borg \& Gall had been adopted with several modifications. Then, the results of the study show that the learning media belongs to the "Very Good" category according to the material expert validation with the mean score 4.38 and that the learning media belongs to the "Very Good" category according to the media expert validation with the mean score 4.23. Furthermore, the results of the limited experiment show that the learning media belongs to the "Very Good" category with the mean score 4.76. Similarly, the results of the expanded experiment show that the learning media belongs to the "Very Good" category with the mean score 4.75 . In order to identify the quality and the effectiveness of the product, an operational test should be performed. The results of the operational test show that the pre-test mean score is 41.65 while the post-test mean score is 89.25 . The mean score of the students has improved with the gap 47.60 points. Therefore, departing from the overall results, the TGFU method-based learning media has been valid and effective for implementation in the learning activities of Sports and Health Education for the Junior High School degree.
\end{abstract}

Keywords: media development, volleyball, TGFU

How to Cite: Fani, R., \& Sukoco, P. (2019). Volleyball learning media using method of teaching games for understanding adobe flash-based. Psychology, Evaluation, and Technology in Educational Research, 2(1), 34-50. doi:http://dx.doi.org/10.33292/petier.v2i1.6

\section{INTRODUCTION}

Education holds a very vital role for maintaining both the nation and the state since education is a tool that might develop and improve the human resources quality. According to the Law Number 20 of 2003 on National Education System (Presiden Republik Indonesia, 2003), the national education serves to: (1) shape and develop the characters and the civilization of the dignified nation in order to enlighten the life of the nation; and (2) develop the potentials of the students so that the students will be individuals who have faith and piety toward God the Almighty, nobility, ultimate health, insights, capacity, creativity and independence and also be democratic and responsible citizens. Then, education lasts for life time and is implemented in the scope of family, school and society. Therefore, education becomes the common responsibility of the family, the society and the government. In relation to the statement, education should be linked to the external school programs, namely the education that possesses the characteristics of a communalism, including scouting.

In relation to the current situations, the information era has been marked by the rapid development of information and communication technology, especially with the development of radio, television, Internet and other wireless network. The characteristics of the development in the technology era are as follows: (1) increasing storage capacity for gathering, saving, manipulating and delivering information; (2) increasing speed of information delivery; (3) device miniaturization; (4) variability on information alternatives; (5) decreasing cost of attaining information; (6) ease in 
operating the products of technology; (7) increasingly rapid and wide distribution of information; (8) better problem-solving initiatives; and (9) more accurate prediction for the future (Miarso, 2004). Therefore, the use of information technology-based tools/media becomes highly important in this century.

The development of the educational technology might not be separated from the changes that take place in the domain of technology and the domain of education. Information technology has experienced extraordinary development. The solid examples of such extraordinary development are electronic portfolio, computer game and simulation, e-book, wireless technology and mobile computing (Purwanto, 2005, p. 10). Thus, by benefitting the technology development, the teachinglearning process will be more interesting and innovative for the students and the technology itself will help the students to be more independent.

Learning is an important activity that each student should perform both inside and outside the school. In fact, several experts argue that learning is the core activity that any student should perform. If the students gain success in the learning process, it might be considered that the students also gain success in their school. Thereby, the students are expected to possess certain skills in their learning. The school as a place in which the students have been learning certainly plays a very vital role in facilitating the students to gain the skills in the learning process. One of the components in the educational system of a school that also takes such responsibility is Sports and Health Education.

The use of information technology device might also be performed to all subjects, including the Sports and Health Education, which has only been considered as outdoor learning process. According to the Curriculum 2006 Textbook, it is stated that the Sports and Health Education does not only cover the practical materials but also the theoretical materials; these theoretical materials should be delivered in the classroom as well. Specific to the practical learning materials, a teacher of Sports and Health Education might benefit the technology device in delivering the materials that should be learned. The technology device might be benefitted by performing numerous learning materials that have been packed onto tutorial videos of numerous sport branches.

Sports and health education is an integral part of overall education. The learning process of Sports and health education aims at developing the aspects of physical fitness, movement skills, critical thinking skills, social skills, reasoning, emotional stability, moral action and healthy life (Bangun, 2012; Hanief \& Sugito, 2015; Kesumawati, Rahayu, \& Rahayu, 2018; Rismayanthi, 2011). These aspects might be gained through the physical, sporty and healthy activities that have been planned systematically in order to achieve the objective of the national education, namely to increase the cognitive, the affective and the psychomotor skills of the students and the social values of the students in the same time. Through a curriculum, the description or the stages in the learning process will be guided. The success of the curriculum implementation should be supported by numerous components, namely: procurement of supporting textbooks, teacher readiness, learning facilities and learning media. The procurement of the supporting textbooks and learning media that might be useful for the students in their learning process will ease the educators to deliver the materials to the students. Then, the presence of the supporting media will assist the students' learning process both inside and outside the school as the students' independent learning materials. The most important thing from the procurement of the learning media is that the materials should be relevant to the national curriculum.

Curriculum serves as the fundamental basis for formulating numerous aspects that have been related to education, including lesson plans. The curriculum itself consists of several materials for the subjects; this also includes the materials of Sports and Health Education and one of the materials in the Sports and Health Education is volleyball. Volleyball has been popularly played in any society. In the domain of education, volleyball have been taught from the Elementary School degree to the Senior High School degree. According to (Viera, Fergusson, \& Monti, 2000, pp. 2-5), volleyball is played by two teams in 30 meter-square (or 9-meter square) are divided by a volley nett and each team consists of 6 players. The court for playing volleyball is 18 meter (590 inch)-length and 9 meter (296 inch)width marked by the side lines and the rear lines. The appropriate height of the nett for the female players is 2.24 meter, while the appropriate height of the nett for the male players and the mixed players is 2.43 meter. The qualified part of the nett is the one between both sidelines. Volleyball should not only be played by relying on the supporting facilities but also the basic techniques and the basic tactics/strategies that the students or the volleyball players master. 


\section{Psychology, Evaluation, and Technology in Educational Research, 2 (1), 2019, 36}

Refatana Asri Fani, Pamuji Sukoco

The learning process for volleyball materials demands a method that might create comfortable, effective and interesting learning environment. In order to ease the conduct of the learning process, many learning methods that might be adopted. Specific to the context of the study, the Teaching Games for Understanding, or also known as TGFU (Kirk \& MacPhail, 2002; Metzler, 2017; Turner \& Martinek, 1999; Werner, Thorpe, \& Bunker, 1996), has been adopted. Teaching Games for Understanding (TGFU) is a learning method that has been based on the game level that is relevant to the learning development and the learning activities in the form of modified games that center on the problems of tactics and how the students solve these problems (Griffin, Mitchell, \& Oslin, 1997). The approach that has been adopted by the TGFU learning method is introducing the definition of sports to the students so that the students can play (Mitchell, Oslin, \& Griffin, 2013). Furthermore, according to (Febrianta \& Sukoco, 2013), a learning process that benefits the tactical approach will facilitate the students to develop the skills in and their capacities of solving the problems in a game. Through the tactical approach, the students will explore their capacities of solving the problems during the game performance; the tactical approach will bring the students immediately into the game situations (Mitchell et al., 2013).

As a teacher candidate of or even as the teacher of Sports and Health Education, the researchers deems that it is necessary to identify and to implement the solutions for the occuring phenomena in the subject. With regards to the statement, the results of the observation toward several schools show that the learning process of volleyball has drawn less enthusiasm among the students. Therefore, the teachers of Sports and Health Education bear heavy responsibility. The teachers should guide and educate the students so that the students will be the constructive individuals who: (1) uphold the Pancasila characters; (2) master the professional integrity; and (3) always maintain good relationship with the fellow students, with the colleagues, with the parents/the family and even with the society. In order to achieve this objective, the teachers should improve their professional quality and their professional organization in addition to understanding the regulations that have been outlined by the government in the domain of education. Fortunately, the relevant Office of Education and Culture has already held workshops, seminars and training programs in order to improve the quality of the teachers in general and the quality of the Sports and Health Education teachers in specific. According to (Suprihatiningrum, 2013), there are five dimensions of capacity that should be fully mastered by a professional teacher. The five dimensions are namely: (1) the commitment to the students and their learning process; (2) the mastery of teaching materials and teaching method; (3) the responsibility to monitor students' capacity through numerous techniques of evaluation; (4) the systematic thinking skills in performing the duties; and (5) the sense of being a part of learning society in his or her professional environment. Through the appropriately packed concept, the students will enjoy the learning process.

Through the concept that has been systematically designed and with the support from the sufficient learning facilities, an enjoyable learning atmosphere might be created. In the era of globalization and the technological advancement nowadays, the teachers are demanded to be able to operate computers/laptops. Therefore, it will be better if the teachers are able to design teaching media by using computer/laptops or at least the teachers are able to access information on the development of the subject that has been taught through the Internet. The increasing demand by the society toward education and the advancement of science and technology has caused the traditional pattern of management irrelevant anymore. The reason is that the traditional pattern of management in education is not compatible to the demands and the needs of the society. Not to mention, the students' learning manner, the communication media advancement and alike have provided certain significance to the educational activities. In the same time, it is also this demand that has encourage the issuance of the policies that benefit the information technology media.

Science indeed has rapidly developed and has entered all aspects of social, economic, political, cultural and educational life. On the aspects of educational life, the focus of the teaching activities nowadays is the effective delivery of learning materials by means of educational media. The presence of the thick textbooks do not boost the reading interest among the students. As a result, there should be a breakthrough that might draw the interest of the students both in the school and in the house. The development of the educational media might be a challenge that provides opportunity for the domain of education in general and the domain of educators in specific to pursue maximum work performance. 
Nowadays, the needs toward the learning media has been increasing. According to (Sadiman, 2003), learning media is not viewed as tool of assistance for an individual anymore but instead learning media is viewed as tool of message delivery." Based on the function of the learning media, learning media should not only be able to be benefitted by the teachers but also by the students. Thereby, learning media should be able to represent the teachers in delivering information accurately, clearly and interestingly.

According to the results of the observation and the interview that have been conducted for the needs analysis and the preliminary study with regards to the learning process of Sports and Health Education within the materials of volleyball in the $1^{\text {st }}$ State Junior High School Godean, the $2^{\text {nd }}$ State Junior High School Godean, the $3^{\text {rd }}$ State Junior High School Godean, the $1^{\text {st }}$ State Junior High School Seyegan, the $2^{\text {nd }}$ State Junior High School Seyegan, the $3^{\text {rd }}$ State Junior High School Seyegan, the $2^{\text {nd }}$ State Junior High School Tempel, the $1^{\text {st }}$ State Junior High School Mlati and the $2^{\text {nd }}$ State Junior High School Mlati, it is found that based on the syllabus the materials of volleyBall belong to the big ball games (Badan Standar Nasional Pendidikan, 2006). Then, the materials that should be taught refer to the materials of the fundamental techniques in playing volleyball or of the fundamental techniques in performing volleyball game. With regards to the materials, during the observation and the preliminary study several findings have been uncovered. First, the materials of volleyball are not completely interesting for the junior high school students because: (1) the learning method that has been adopted is inappropriate (lecture); and (2) there are not any learning media that might be used during the learning process. Second, the learning media for teaching the theoretical materials of Sports and Health Education have been insufficient. The only media that have been available are the student worksheets whereas in the learning process the theoretical activities demand interesting, effective and efficient learning sources. Third, the allocation of time composition for the Sports and Health Education has been limited especially for the learning materials of volleyball. Fourth, the students' interestingness and learning motivation toward the volleyball game have been low and the statement has been confirmed by the students' lack of motivation in learning volleyball. The reason is that the learning process of volleyball game has not been supported by the current textbooks or the current media about the volleyball; consequently, the students possess insufficient knowledge about volleyball

Departing from the overall results of preliminary observation and field study toward the seven state junior high schools, it is found that the learning process of Sports and Health Education in the Junior High School degree has still relied on the conventional method namely that the teachers of Sports and Health Education generally deliver the learning materials by means of lecture. The teachers give explanation, give assignment and perform technical exercise without using any interesting learning method and, thus, the students become highly bored in attending the learning process. Seven teachers generally give explanation (lecture) and then directly perform the fundamental techniques in the volleyball. In addition, the students state that usually the teachers of Sports and Health Education perform warming up, give explanation, give several examples and then practice the volleyball. As a result, the students perform the fundamental technique of volleyball inasmuch as they can without knowing whether the techniques that they have performed is right or wrong.

The learning process of volleyball has been less interesting because the teachers of the Sports and Health Education only perform the fundamental techniques. This is the reason why the students are less enthusiastic or even less interesting in attending to the learning process of volleyball in the Sports and Health Education. The results of the interview with the students who have been randomly selected from the seven state junior high schools that have been sampled provide several implications. $72.00 \%$ of 50 students state that during the learning process of volleyball the students are provided with the volleyballs and are asked to play the volleyball game immediately after the teachers have finished their lecture. On the other hand, $86.00 \%$ of 50 students state that the learning process of volleyball that they have retrieved is less interesting and less various so that the students easily get bored. It is apparent that the teachers of Sports and Health Education from the seven state junior high schools that have been sampled still implement the teacher-centred method and, thereby, the students are not actively engaged in the learning process. The methods that have been implemented in the learning process for several materials, including volleyball, have led to the discrepancy between the materials that should be delivered and the delivery method that should be adopted. Based on the observation, the fact that has been found implies that the students do not optimally attend the learning process. Due to this situation, the impact is that most of the students have not passed the Minimum 
Passing Grade (KKM, Kriteria Ketuntasan Minimal). However, apart from this finding, some teachers still carry out their duty well and maximally within the learning process.

Both teacher and teacher candidate should be creative in delivering the learning materials through both the appropriate method and the relevant learning media. Teachers are demanded to have high level of creativity so that he or she might develop the appropriate concept or method within the conduct of the learning process. The implementation of the appropriate learning method will improve the students' motivation in attending the learning process; in turn, the implementation of the appropriate learning method might bring about positive results to the students' activeness. From the perspective of the learning process, there should be learning media that might be benefitted for achieving that end. One of the learning media is multimedia. Multimedia might be an appropriate alternative media for supporting the learning process of the Sports and Health Education both inside and outside the classroom. Multimedia is more appropriate to adopt in comparison to PowerPoint and poster because multimedia is able to provide clear concept and description.

Based on the results of the needs analysis, in general it might be proposed that the development of the learning media by using the information technology device, namely Adobe Flash CS6 Professional, for the students of junior high school degree is fit for manufacture. Then, the Adobe Flash CS6 Professional has been selected as the software for the development of the learning media application because it is necessary to introduce the learning materials of volleyball in the form of $\mathrm{CD}$ (Compact Disc) so that the students might be facilitated in understanding the materials. This program is able to display interesting multimedia application complete with the supporting features; in fact, this program is supported by many interesting animations and easy to operate. This program might be adjusted to the competences that should be achieved, the characteristics of the students, the conformity between the teachers and the students, the cost and the other supporting aspects. The use of Adobe Flash CS6 Professional-based learning media that will be available in the CD is expected to improve the students' motivation in learning volleyball and to be the independent learning sources or the independent teaching materials.

Thus, the study is conducted in order to develop an innovation within the learning process of Sports and Health Education. Specifically, the study is conducted in order to pursue the innovation on the learning process of volleyball by using the Adobe Flash CS6 Professional as the basic software for the learning media design. Through the development of the product, it is expected that the needs toward the interesting learning media for delivering the materials of volleyball.

\section{METHOD}

In this section, the method that had been adopted in the study was elaborated. The elaboration of the method consisted of development model, development procedures, experiment design, experiment subjects and data gathering technique and instrument. Each of these aspects might be consulted in the following section.

\section{Development Model}

The study was a Research \& Development (R\&D) initiative. According to (Gall, Gall, Borg, \& Gall, 2003, p. 569), research and development (R\&D) is an industry-based development model in which the findings of research are used to design new products and procedures, which then are systematically field-tested, evaluated and refined until they meet specified criteria of effectiveness, quality or similar standards.

\section{Development Procedures}

The development procedures in the study referred to the stages that had been developed by Borg $\&$ Gall. In relation to the procedures, every researcher has the right to define and select the most appropriate stage for the research and development initiative based on the conditions and obstacles that should be dealt with (Ardiyanto \& Fajaruddin, 2019; Dwiyogo, 2004). Therefore, the stages in the research and development initiative of the study were simplified in accordance to the conditions and the obstacles that had been found. Then, according to (Sugiyono, 2015, p. 75) the stages in conducting a research and development study might be as follows: (1) data gathering; (2) information analysis; (3) preliminary product (model draft) development; (4) expert validation and revision; (5) limited scale 
experiment and revision; (6) expanded scale experiment and revision; (7) final product generation; and (8) product effectiveness test .

\section{Experiment Design}

The experiment design was intended to attain direct feedback from the users with regards to the learning media that had been developed. Prior to the experiment, the product should be validated first by the material experts and the media experts. After having attained the feedback, several revisions should be made. After the revision had been completed, the model that had been developed should go through the experiment and this experiment consisted of two stages namely the limited experiment and the expanded experiment. The aim of conducting this experiment is to identify the weakness, the drawback, the errors and the feedback for improvement so that the product, or the model, that had been developed might be revised in order to attain the valid and fit product for the learning process of Sports and Health Education.

\section{Experiment Subjects}

The subjects that had been selected within the research and development initiative were the Grade VIII students from the Junior High School degree based on the results of the consultation with the experts. In accordance to the stages in the research and development, the data were gathered from the junior high school students as the subjects of the study. Then, within the study the field experiment, consisting of the limited experiment and the expanded experiment, and the operational test were conducted. For the limited experiment, the subjects were 31 students from one grade in the $1^{\text {st }}$ State Junior High School Seyegan. Then, for the expanded experiment, the subjects were 62 students from two different junior high schools namely the $3^{\text {rd }}$ State Junior High School Godean and the $1^{\text {st }}$ State Junior High School Mlati. Last but not the least, for the operational test of the questionnaire instrument and the test instrument the subjects were 28 students from one grade in the $1^{\text {st }}$ State Junior High School Godean.

\section{Data Gathering Technique and Instrument}

The techniques that had been used in gathering the data for the study was questionnaire and interview. Then, the instruments that had been used for gathering the data within the study were: (1) needs analysis instrument; (2) preliminary study sheet; (3) evaluation sheet for material expert; (4) evaluation sheet for media expert; and (5) evaluation sheet for students. Then, the questionnaire that had been designed was intended to evaluate the quality of the learning media. On the other hand, the researcher also developed interview guidelines in order to gather the useful suggestions, criticisms and feedback from the experts and the students so that the product might be improved into well-qualified learning media.

The instruments that had been used were adopted from the instruments that had been administered in previous studies. Then, these instruments were tested in terms of validity and reliability. For testing the questionnaire, the construct validity test was conducted. After the construct validity test had been completed, the instrument was developed in accordance to the theoretical reviews and the research variables. When the development had been done, the instrument was sent to the experts in order to gather the necessary feedback.

Sugiyono $(2015$, p. 122) states that instrument reliability is a prerequisite for the conduct of the instrument validity test. On the other hand, (Arikunto, 2016) states that reliability refers to the level of trustworthiness that an instrument has. Every measurement tool should have the capacity to provide relatively consistent measurement results from one time to another.

The objective of conducting the validity and the reliability test within the study was to meet the absolute prerequisite in data gathering activities by through the instrument that had been tested and that had been able to measure the necessary data. Then, the test instrument itself consisted of 12 items. On the other hand, the validity test was performed by involving the students as the subjects for the instrument test. The reliability test for the instrument was conducted by using Bilogmg 3.0.

\section{RESULTS AND DISCUSSIONS}

The results that have been gathered from the conduct of several tests in the study will be discussed further in this section. The discussion itself will be related to the product development and 
the feedback from the experts and the students. Each aspect within the discussion might be consulted in the following sub-section.

\section{Learning Media Development}

The learning media that have been designed should undergo the Preliminary Stage, the Planning Stage and the Design Development Stage. After the three stages have been completed, the subsequent stage is Media Development Stage. In this stage, the flowchart for the media designed is drafted. The objective of drafting the flowchart is to prepare the graphic that will serve as the basis for the media development. The flowchart in the Media Development Stage might be consulted in Figure 1.

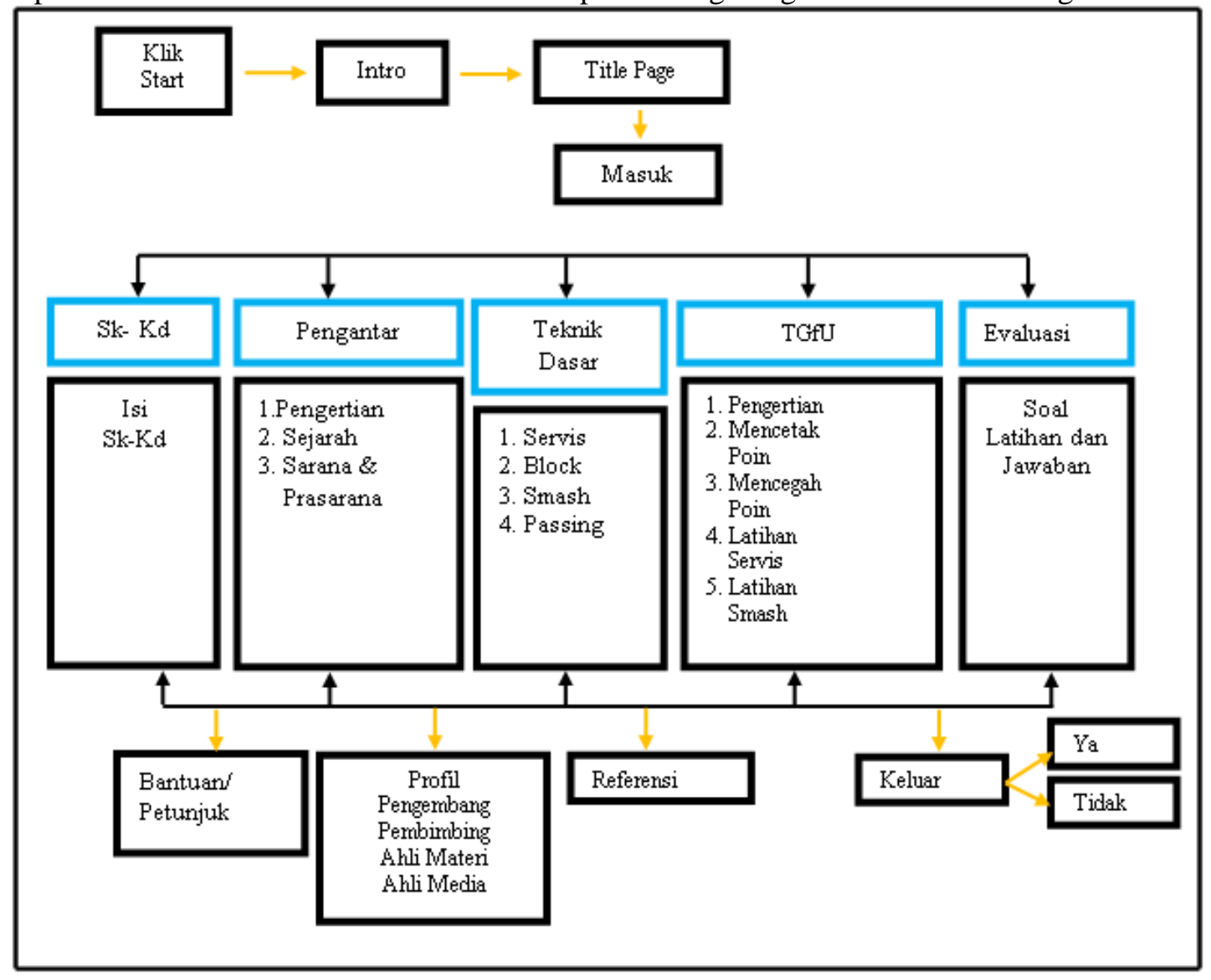

Figure 1. Flowchart View

\section{Description on the Results of the Preliminary Product Development}

The product that has been generated in the Research and Development initiative within the study is a CD of Adobe Flash-based TGFU method for the volleyball learning process. This product contains several learning materials of volleyball that have been designed by using the Adobe FlashBased TGFU method. The Adobe Flash itself refers to the Adobe Flash CS6 Professional. This software is able to create interactive, interesting and dynamic presentations, games, films, CDs (including CDs for learning activities) and web sites. The layout for the preliminary product altogether with the other aspects of volleyball learning process that has been designed by using the Adobe Flashbased TGFU method might be consulted in the following sub-sections.

Title Page

Figure 2 displays the title page for the learning media. This page contains the Entry button, which serves to open the content of the media, and the Return button, which brings the users to the Foreword part of the learning media. 
Psychology, Evaluation, and Technology in Educational Research, 2 (1), 2019, 41

Refatana Asri Fani, Pamuji Sukoco

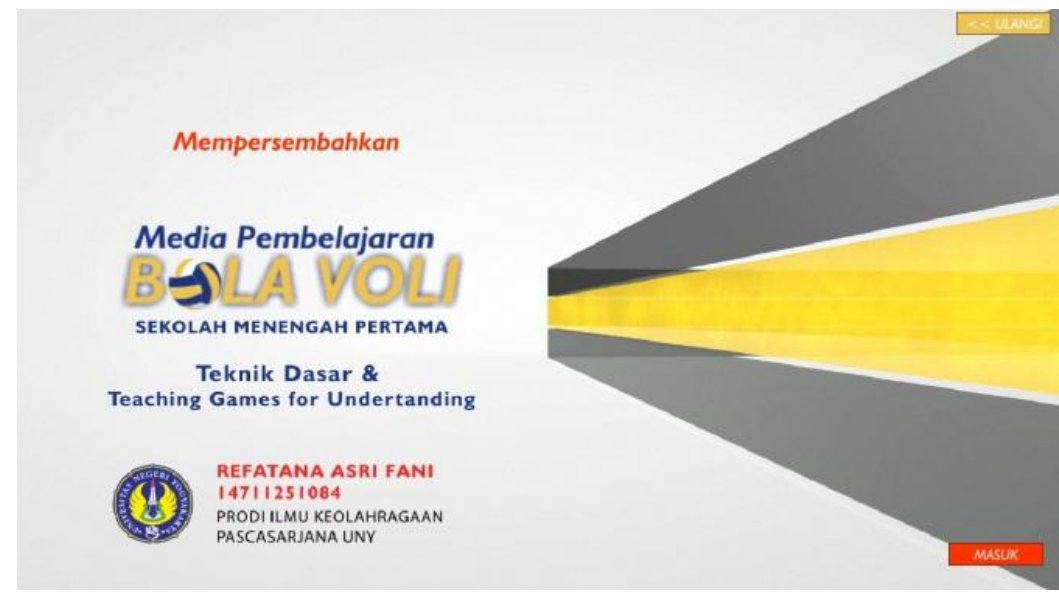

Figure 2. Title Page

Enter

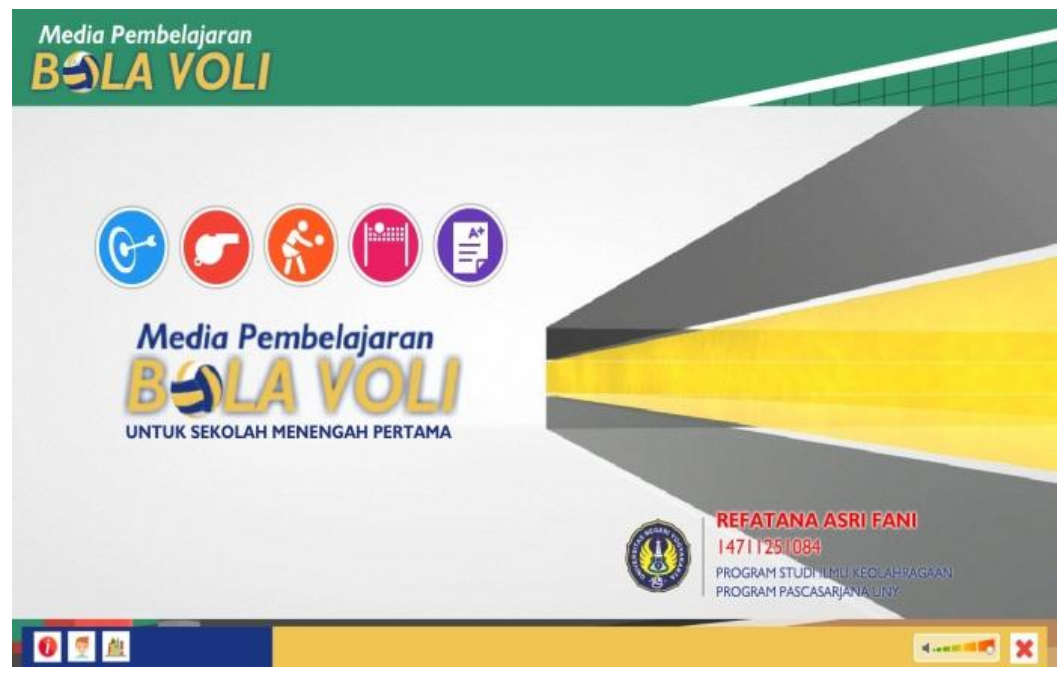

Figure 3. Main Page

The Enter button above brings the user into the main page of the learning media. In this main page, the users will find the Competence Standards-Basic Competences section, the Introduction section, the Basic Technique section, the Teaching Games for Understanding Method section, the Evaluation/Exercise section, the Help section, the Profile Section and the References section.

Standard Competences/Basic Competences

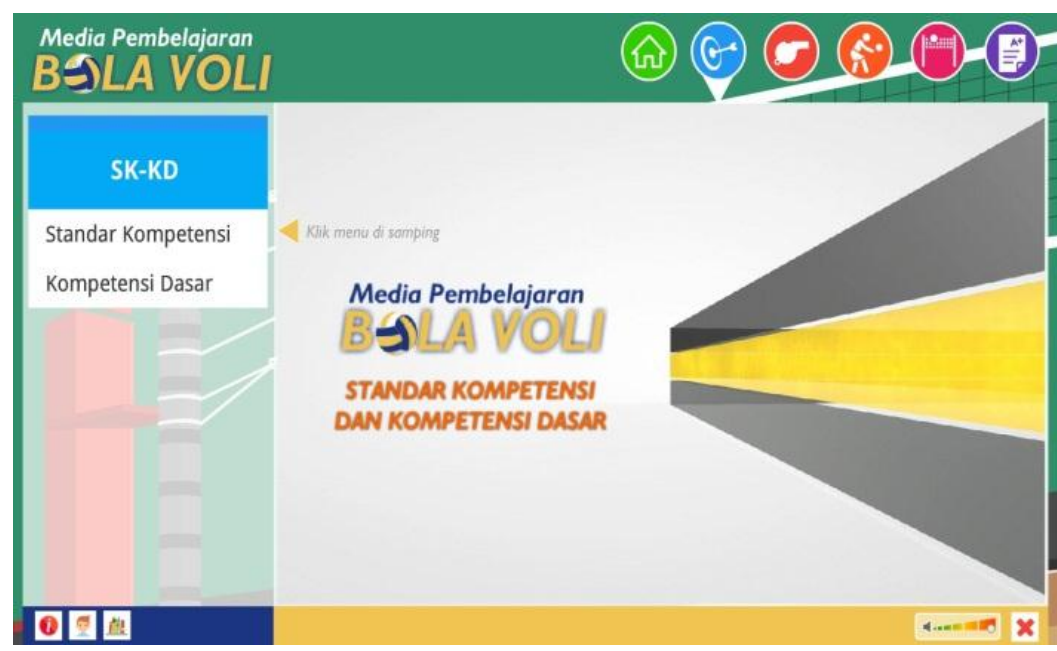

Figure 4. Layout of Standard Competences/Basic Competences Section 
If the user click the menu Standard Competences/Basic Competences section, then the Standard Competences/Basic Competences for the learning materials of volleyball Game will appear to the screen. These learning materials have been designed by using the TGFU method.

Introduction

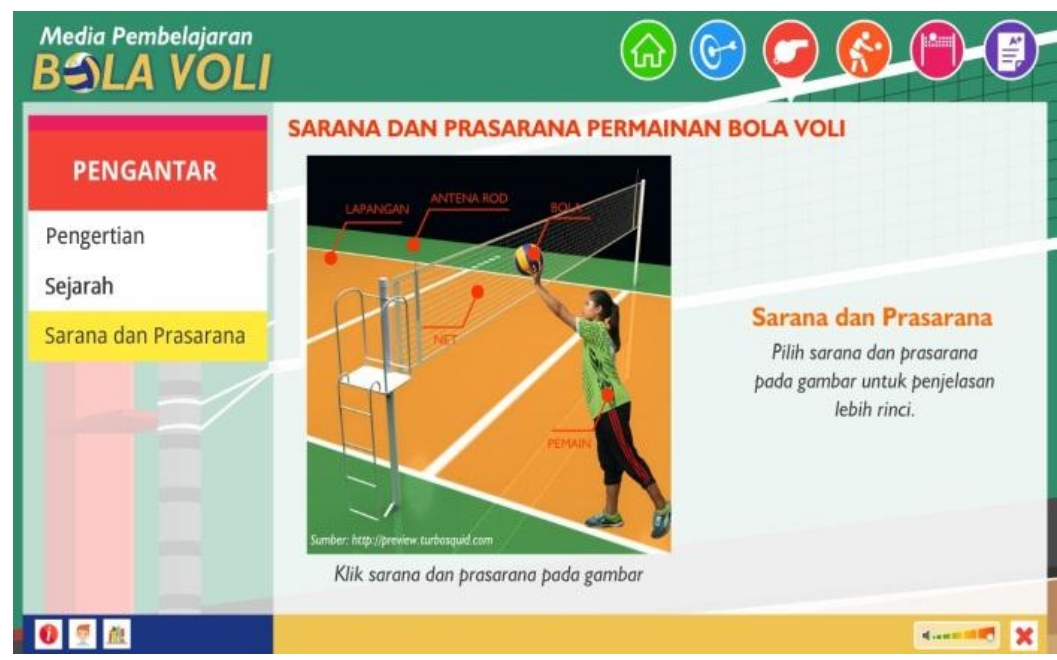

Figure 5. Layout of Introduction

If the users click the Introduction section, then the Introduction section will appear on the screen as having been displayed in Figure 5. This section consists of three parts namely Definition, History and Facilities. If the users click one of the three parts, an explanation on the given part will appear to the screen.

Basic Technique

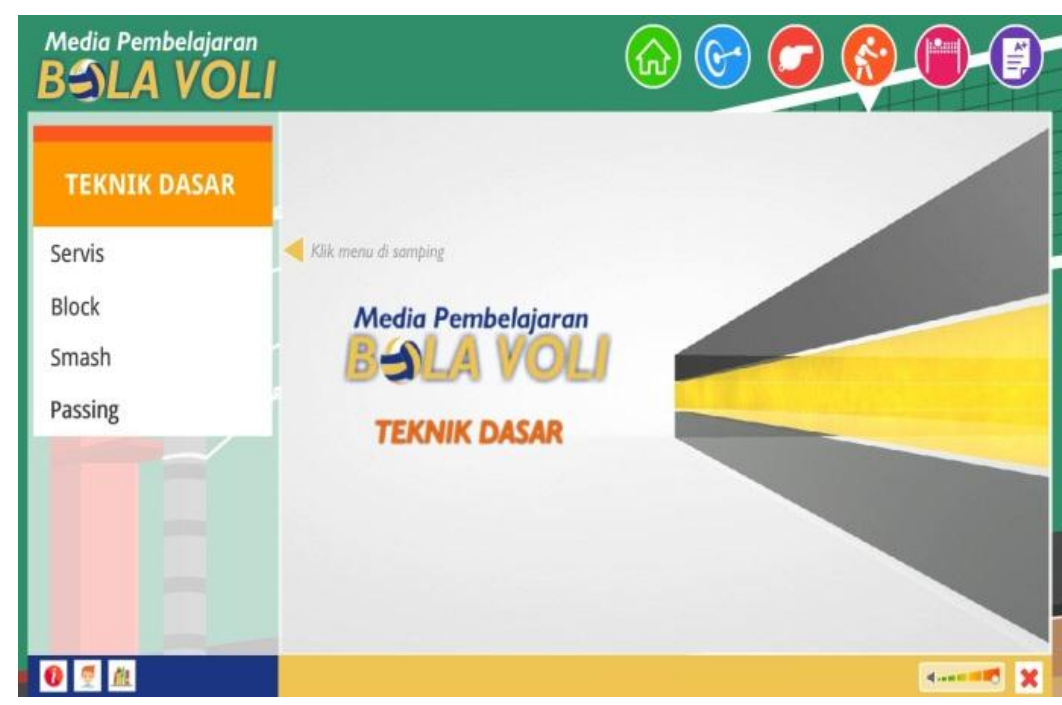

Figure 6. Layout of Basic Technique

If the users click on the Basic Technique section, the layout that has been displayed in Figure 6 will appear to the screen. The Basic Section Technique consists of four parts namely Service, Block, Smash and Passing. If the users click one of these parts, then an explanation on the given part will appear to the screen.

\section{Materials}

This part of the learning media displays the compulsory materials. Each material consists of sub-materials as having been displayed in Figure 8. When the users hover the cursor to one of the materials that have been available, the writings will be colourful and explanation on the given 
materials appear to the surface. Then, if the users click on the explanation the layout of video will appear on the screen as having been indicated by Figure 9 .

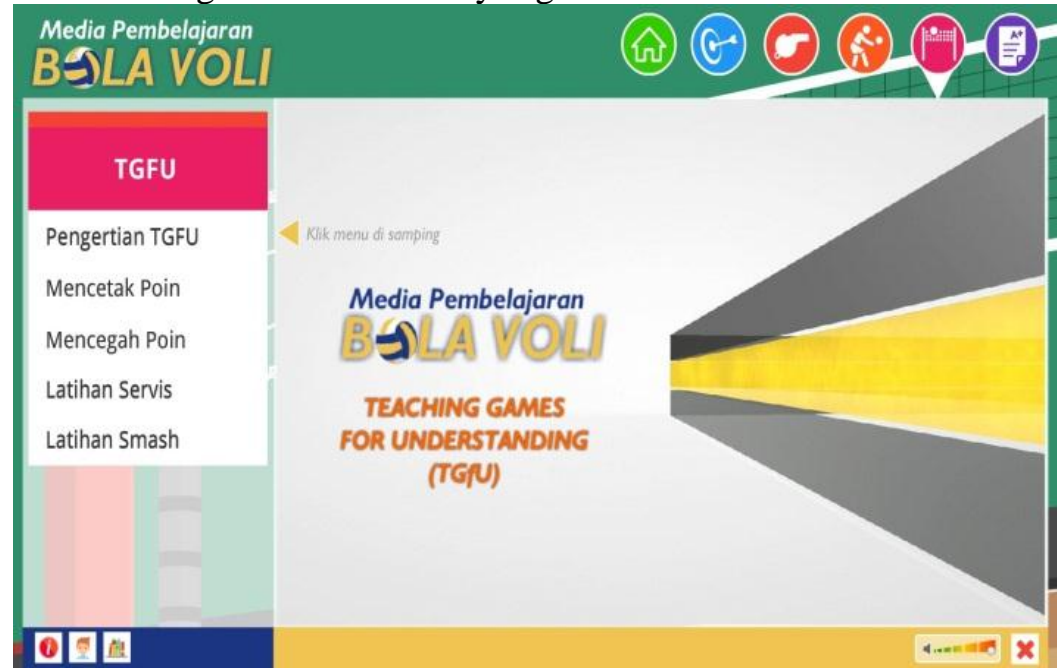

Figure 7. Layout of Materials

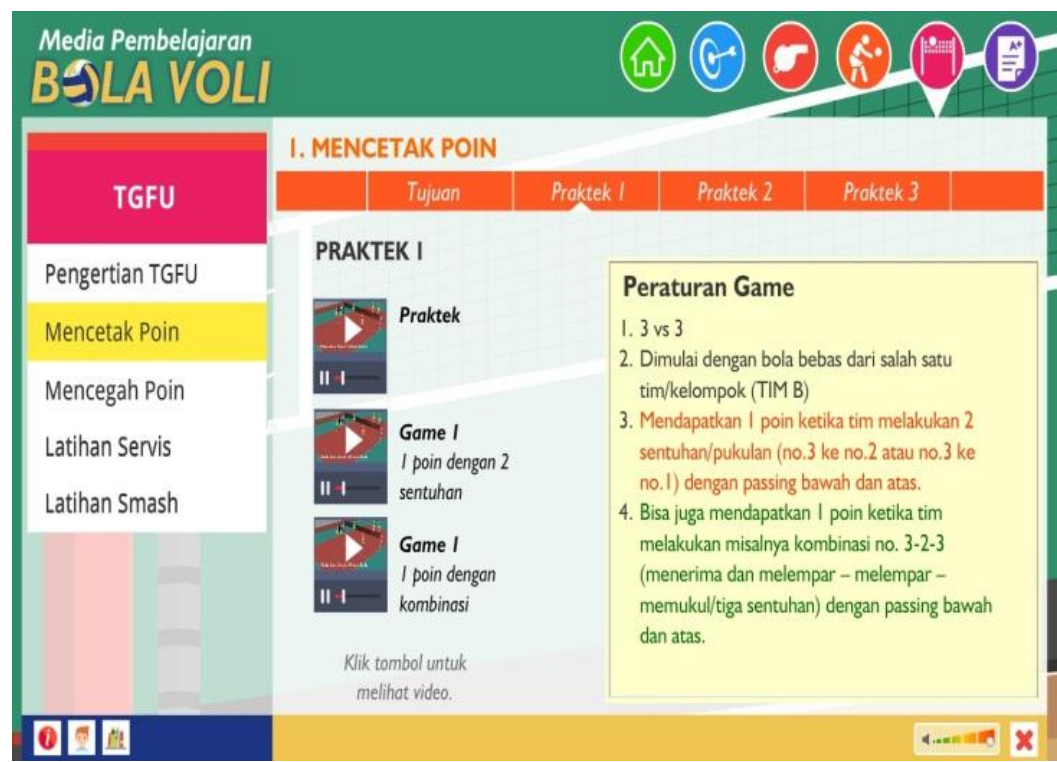

Figure 8. Layout of Materials after Having been Clicked

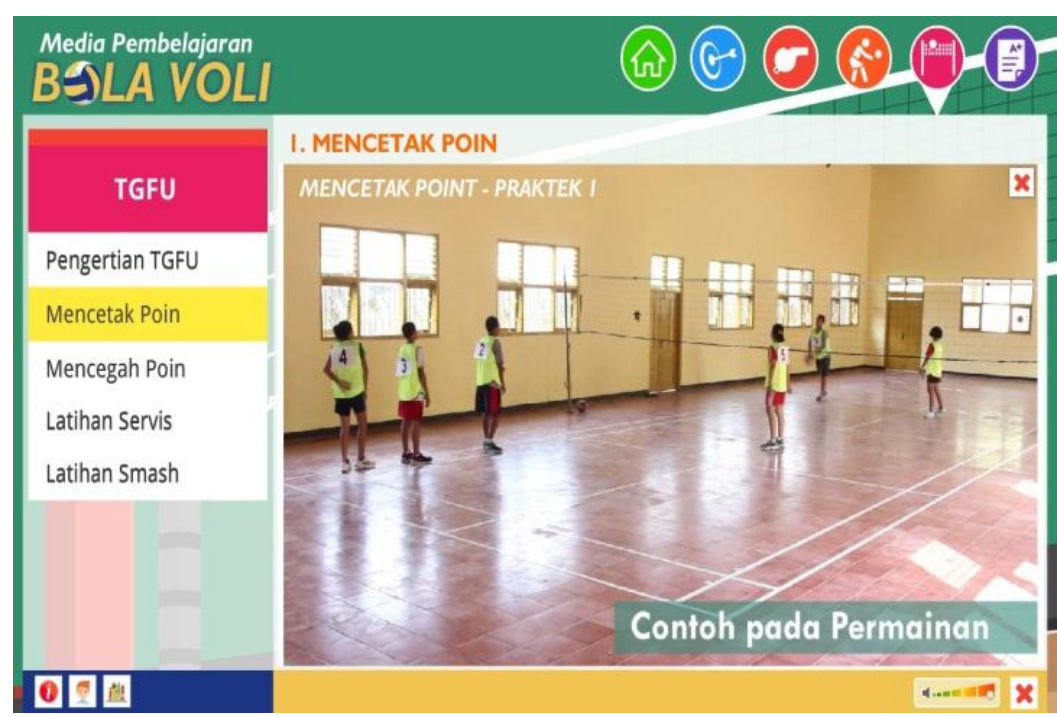

Figure 9. Layout of Video 
Psychology, Evaluation, and Technology in Educational Research, 2 (1), 2019, 44

Refatana Asri Fani, Pamuji Sukoco

\section{Evaluation/Exercise}

Figure 11 displays the layout of the Evaluation section. The users might complete this evaluation items by hovering and clicking the correct alternatives (A, B, C or D). After the evaluation items have been completed, the results will displayed on the screen. The layout of the results is displayed in Figure 12.

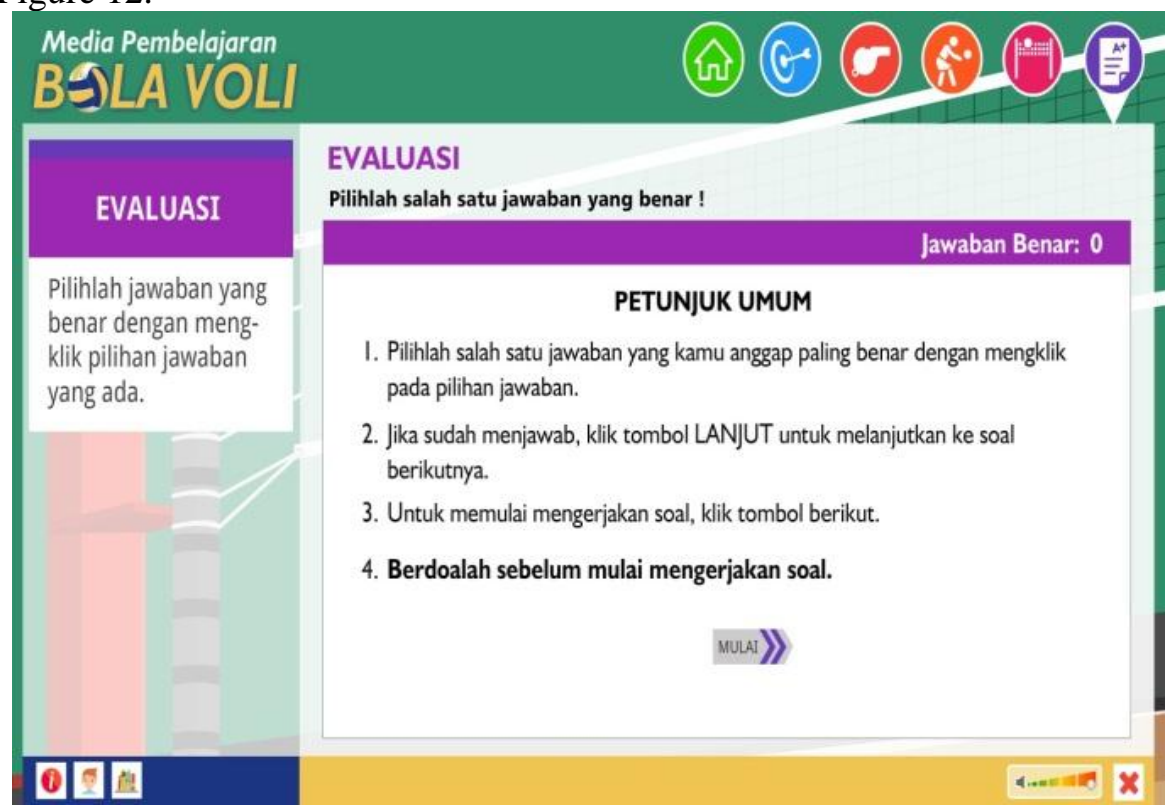

Figure 10. Layout of Evaluation

\section{Media Pembelajaran $B S) L A$ VOLI}

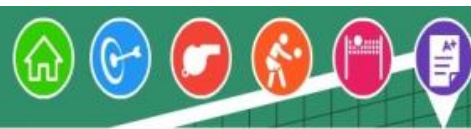

\section{EVALUASI}

Pilihlah jawaban yang benar dengan mengklik pilihan jawaban yang ada.

\section{EVALUASI}

Pilihlah salah satu jawaban yang benar !

I. Perhatikan gambar a di bawah ini !

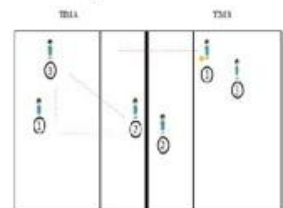

Pada permainan bola voli tujuan mendapatkan poin/angka dengan 2 sentuhan (lihat gambar a). Tim B melakukan servis ke arah siswa no. 3 , selanjutnya siswa no.3 harus mengoper/melempar kemana dan siswa yang menerima bola melakukan apa?

\section{a. 3 ke 2 dan melakukan pukulan/memasukkan bola}

b. 3 ke I dan melakukan pasing bola

c. 3 ke I, I ke 2 dan melakukan memainkan bola

d. d.3 ke 2, 2 ke I dan melakukan pukulan/memasukkan bola

Figure 11. Layout of Evaluation 


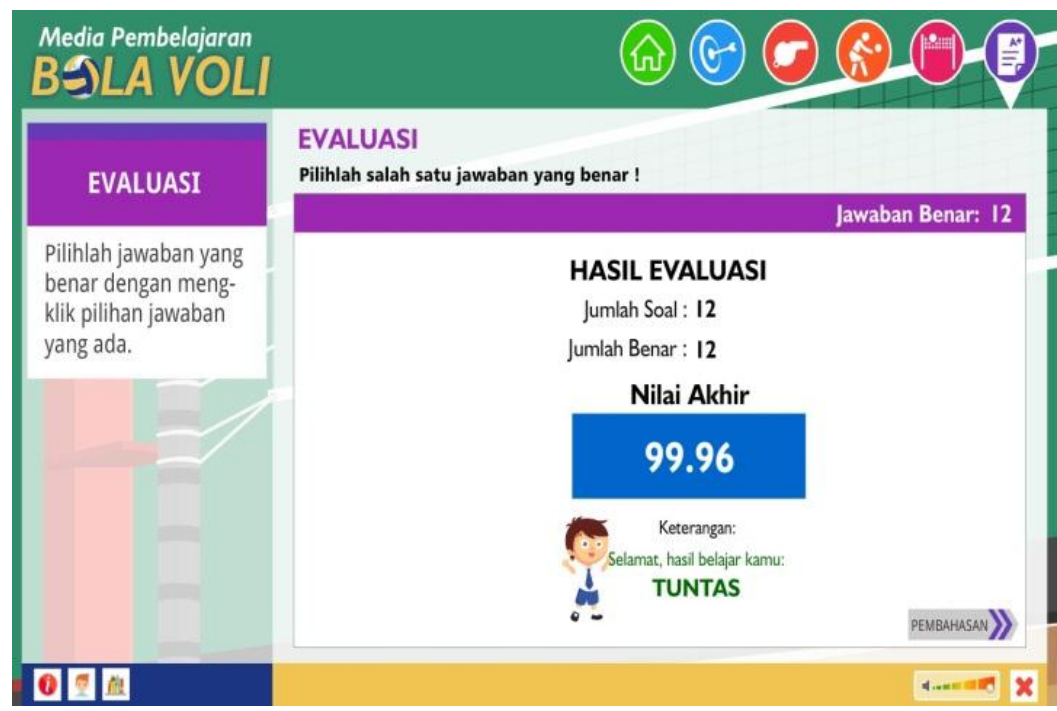

Figure 12. Layout of Evaluation Results

Profile

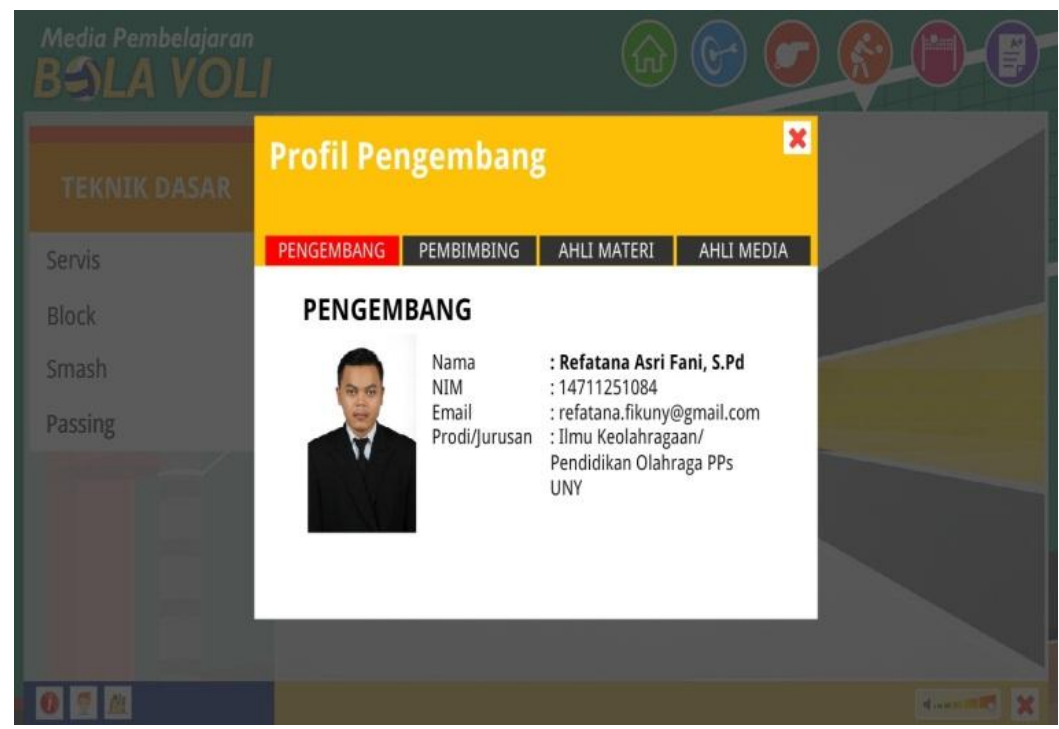

Figure 13. Layout of Profile

If the users click on the Profile section, then the layout displayed in Figure 13 will appear on the screen. The Profile section consists of four parts namely Profile of the Developer, Profile of the Supervisor, Profile of Media Expert and Profile of Material Expert. If one of this parts is clicked, an explanation on the given part will appear on the screen.

\section{Results of Limited Experiment}

For the conduct of the limited experiment, the subjects were 31 students from the 1 st State Junior High School Seyegan. The data were gathered from the questionnaire and the data that had been gathered were analysed in order to serve as the basis for the revision. Then, the data that had been gathered from the questionnaire consisted of three aspects namely Aspects of Layout (10 items), Aspects of Content or Materials ( 7 items)and Aspects of Learning Process (11 items).

The data that have been gathered from the conduct of the limited experiment show that the learning media belongs to the "Very Good" category. This statement has been confirmed by the mean score of each aspect as follows: (1) 4.79 for the Aspects of Layout with "Very Good" category; (2) 4.68 for the Aspects of Content or Materials with "Very Good" category; and (3) 4.81 for the Aspects of Learning Process with "Very Good" category. Therefore, it might be concluded that the learning media belongs to the "Very Good" category with the mean score 4.76. The results of the limited 
experiment for the Aspects of Layout, the Aspects of Content or Materials and the Aspect of Learning Process might be consulted in Table 1 and Figure 14.

Table 1. The Results of Product Assessment from the Limited Experiment

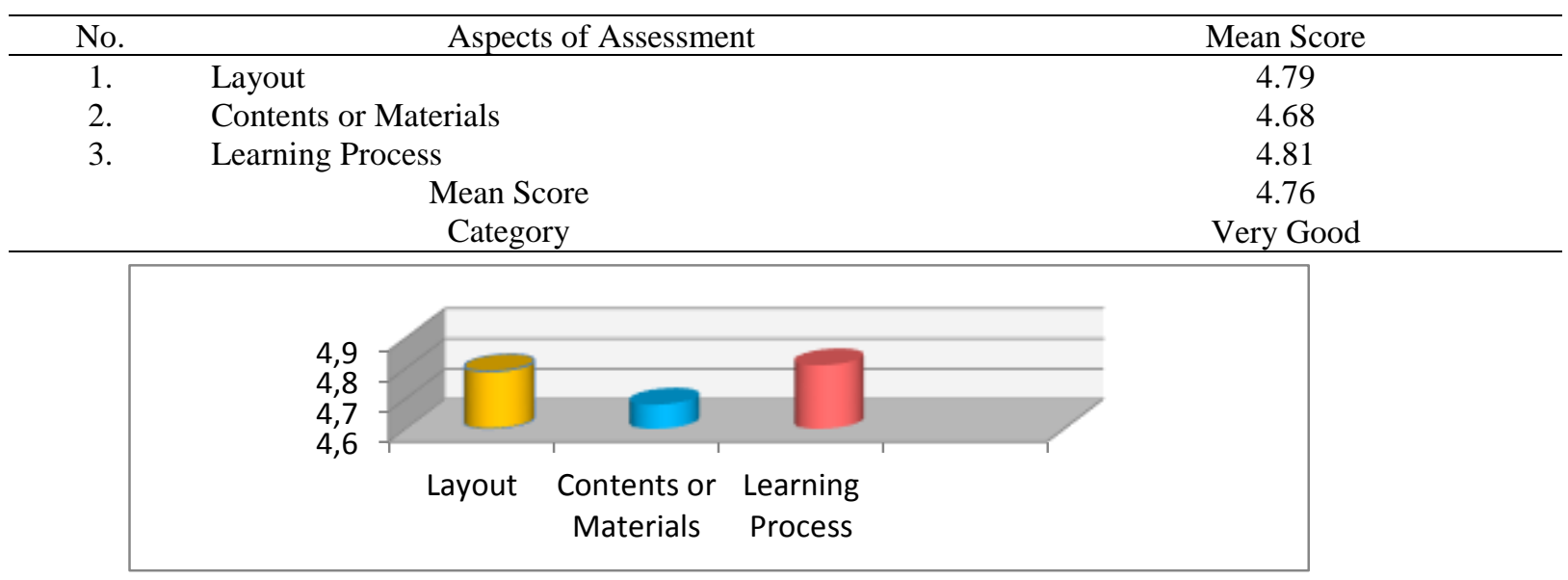

Figure 14. The Graphic of Product Quality from the Limited Experiment

\section{Results of Expanded Experiment}

The conduct of the expanded experiment involved two state junior high schools namely the $3^{\text {rd }}$ State Junior High School Godean and the $1^{\text {st }}$ State Junior High School Mlati with the total number of the subjects 62 students. The data were gathered by means of questionnaire, which consisted of three aspects of assessment namely Aspects of Layout (10 items), Aspects of Contents or Materials (7 items) and Aspects of Learning Process (11 items). Within the conduct of the expanded experiment, the students were facilitated in using the computers personally as they operated the learning media. The students were invited to provide their response toward the learning media that had been used. The response and the information with regards to the comments and the suggestions toward the learning media were observed and were documented by the researchers.

The data from the expanded experiment results show that the learning media that have been developed belongs to the "Very Good" criteria. In specific, the expanded experiment results show that the mean score for the Aspects of Layout belong to the "Very Good" category with the mean score 4.76, the Aspects of Contents or Materials belong to the "Very Good" category with the mean score 4.69 and the Aspects of Learning Process belong to the "Very Good" category with the mean score 4.79 .

From the activities in the expanded experiment, it is found that the students seem to be curious and enthusiastic in using the learning media. The students perform the learning activities from the beginning until the end fluently. In the same time, it is also found that the students repeat learning the materials whenever they do not have clear understanding; in fact, some of the students take notes on the learning materials. Therefore, based on the overall results of the expanded experiment with 62 students as the subjects with regards to the Aspects of Layout, the Aspects of Contents or Materials and the Aspects of Learning Process, it might be concluded that the learning media belongs to the "Very Good" category with the mean score 4.75. The results of the student assessment in the expanded experiment and the score that has been assigned to the Aspects of Layout, the Aspects of Contents or Materials and the Aspects of Learning Process might be consulted in Table 2 and Figure 15.

Table 2. The Results of the Product Assessment in the Expanded Experiment

\begin{tabular}{|c|c|c|}
\hline No. & Aspects of Assessment & Mean Score \\
\hline 1. & Layout & 4.76 \\
\hline 2. & Contents or Materials & 4.69 \\
\hline 3. & Learning Process & 4.79 \\
\hline & Mean Score & 4.75 \\
\hline & Category & Very Good \\
\hline
\end{tabular}




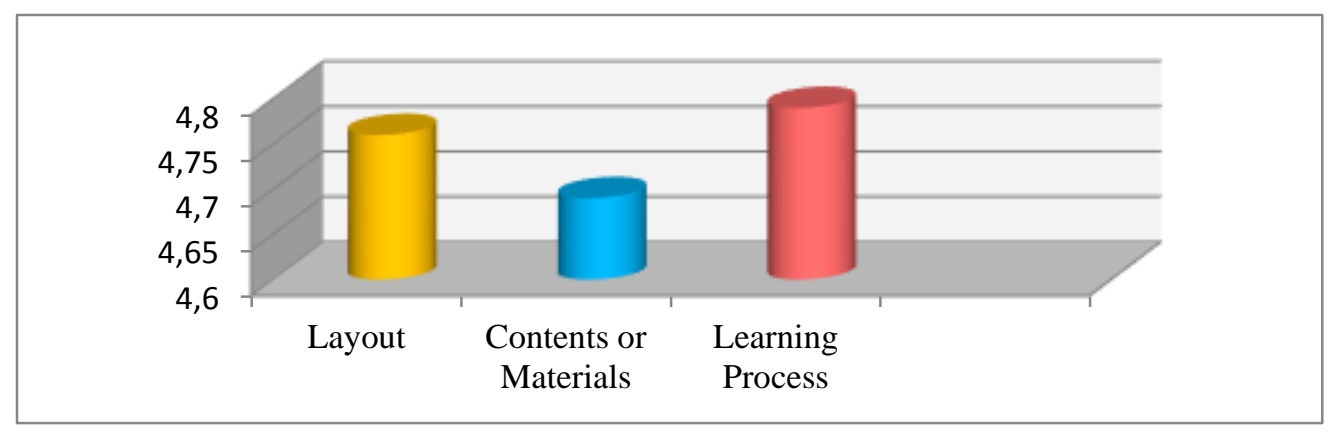

Figure 15. The Graphic of the Product Assessment Results in the Expanded Experiment

\section{Results of Operational Field Test}

The operational field test was performed in order to test the learning media readability by the teacher and the product effectiveness by the students. The conduct of the operational field test thus involved the teacher for the product readability assessment and the 28 students from the $1^{\text {st }}$ State Junior High School Godean as the subjects for the product effectiveness assessment. The teacher operated the learning media, while the assessment was conducted through interview. On the other hand, the students administered the pre-test activities in order to identify their preliminary level of understanding about the learning materials that have been designed by using Adobe Flash-based TGFU method. In this regard, the test instrument consisted of 12 items.

In the subsequent stage, the students attended to the learning process by using the learning media in the computer laboratory. In this stage, the data were gathered by using the questionnaire, which consisted of three aspects namely the Aspects of Layout (10 items), the Aspects of Contents or Materials (7 items) and the Aspects of Learning Process (11 items). In the operational field test, the students were facilitated by the personal computers in operating the learning media. The students were invited in order to provide their response toward the media that had been operated. The response and the information with regards to the comment and the suggestions by the students toward the learning media were observed and documented by the researchers. After the whole sequence in the operational field test had been completed, the students administered the post-test activities. The post-test activities were administered in order to identify the students' capacities in learning the materials that had been displayed in the learning media. The test instrument in the post-test consisted of 12 multiple-choice items.

The data from the questionnaire of the operational field test show that the learning media belongs to the "Very Good" category. Specifically, the data from the questionnaire of the operational field test show that the mean score for the Aspects of Layout is 4.85 with the "Very Good" category, the mean score for the Aspects of Contents or Materials is 4.80 with the "Very Good" category and the Aspects of Learning Process is 4.87 with the "Very Good" category. Therefore, based on the overall results of the operational field test with 28 students from the $1^{\text {st }}$ State Junior High School Godean as the subjects, it might be concluded that the learning media that has been developed belongs to the "Very Good" category with the mean score 4.84. Then, the results of the assessment by the students with regards to the Aspects of Layout, the Aspects of Contents or Materials and the Aspects of Learning Process might be consulted to Table 3 and Figure 16.

Table 3. The Results of the Product Assessment in the Operational Field Test

\begin{tabular}{clc}
\hline No. & & Aspects of Assessment \\
\hline 1. & Layout & Rata-rata \\
2. & Contents or Materials & 4.85 \\
3. & Learning Process & 4.80 \\
& Mean Score & 4.87 \\
& Category & 4.84 \\
\hline
\end{tabular}




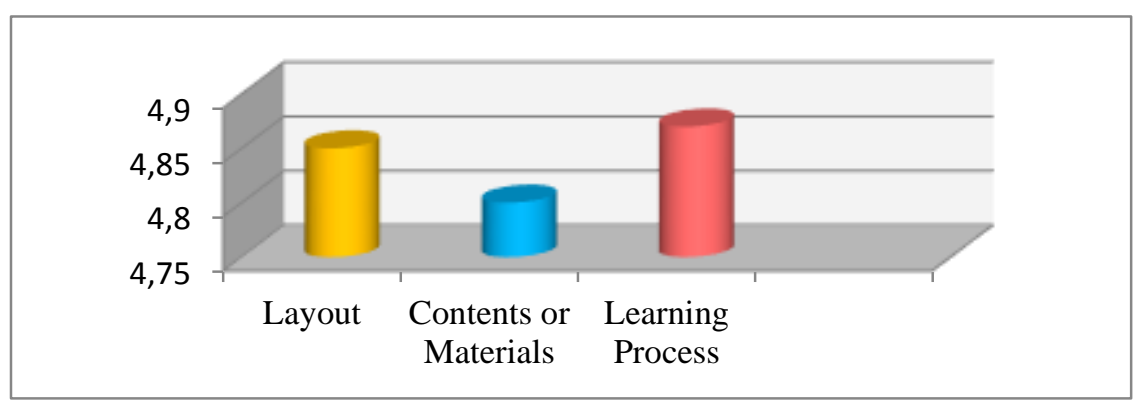

Figure 16. The Graphic of Product Assessment Results in the Operational Field Test

The operational field test has given improvement on the mastery of the learning materials that have been designed by using the Adobe Flash-based TGFU method. The improvement on the mastery of the learning materials that have been designed by using the Adobe Flash-based TGFU method might be consulted in Table 4 .

Table 4. The Results that Have been Gathered from the Test Instrument

\begin{tabular}{clccc}
\hline No. & & Test & Score & Mean Score \\
\hline 1. & Pre-Test & & 1166.20 & 41.65 \\
2. & Post-Test & 2499.00 & 89.25 \\
& Score Gap & & 47.60 \\
\hline
\end{tabular}

Departing from the results of the calculation on the level of the students' mastery, it is apparent that the mean score of the pre-test is 41.65 with the total score 1166.20. After the learning media have been operated, the level of the students' mastery has improved. This improvement is confirmed by the mean score of the post-test namely 89.25 with the total score 2499.00 . Thus, the gap between the pretest mean score and the post-test mean score is 47.60 . Therefore, it might be convincedly concluded that there has been improvement on the mastery of the learning materials after the learning media that has been designed by using the Adobe Flash-based TGFU method is implemented. The improvement might be consulted to the Figure 17.

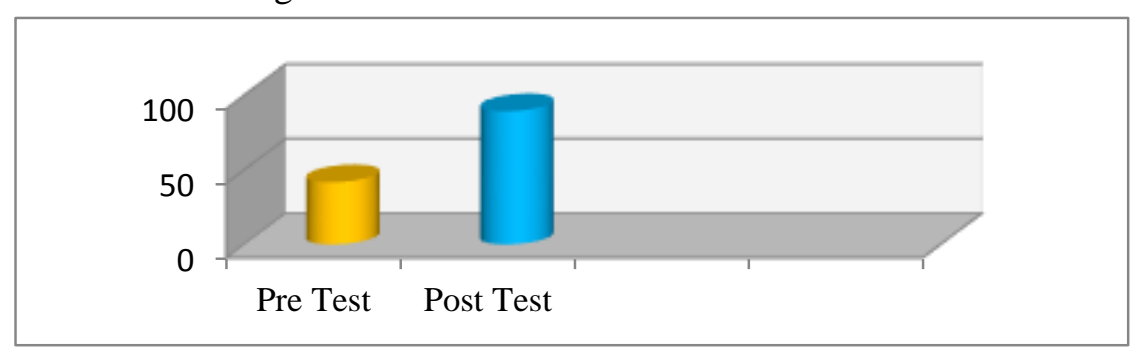

Figure 17. The Graphic of Improvement as Having been Displayed by the Results in the Test Instrument

\section{CONCLUSIONS}

A learning media for the learning materials of volleyball has been developed by using the Adobe Flash-based TGFU method for the students of the junior high school degree. In relation to the statement, and also based on the results and the discussions within the study, there are several points of conclusions that might be proposed. First, the final product of the learning media that has been developed by using the Adobe Flash-based TGFU method for the students of the junior high school degree is Compact Disc. The Compact Disc contains the learning materials of volleyball and the TGFU method. Second, the basic techniques that have been included into the learning materials of volleyball are service, block, smash and passing. Third, the TGFU method that has been inserted consists of scoring point, intercepting point, practicing service, practicing smash and performing evaluation. Fourth, based on the stages that have been gone through, namely the expert judgment and the group experiment, several implications have been found. According to the material expert, the Aspects of Contents or Materials belong to the "Very Good" category with the mean score 4.38. On 
the other hand, according to the media expert, the Aspects of Layout and the Aspects of Programming belongs to the "Very Good" category with the mean score 4.23. Furthermore, the results of the student assessment in the limited experiment show that the Aspects of Layout, the Aspects of Contents or Materials and the Aspects of Learning Process altogether belong to the "Very Good" category with the mean score 4.76. Subsequently, the results of the expanded experiment show that the Aspects of Layout, the Aspects of Contents or Materials and the Aspects of Learning Process belong to the "Very Good" category with the mean score 4.75. Similarly, the results of the operational field test show that the Aspects of Layout, the Aspects of Contents or Materials and the Aspects of Learning Process belong to the "Very Good" category with the mean score 4.84. Within the conduct of the operational field test, another test should be conducted namely the test instrument experiment. In relation to the test instrument experiment, the comparison between the pre-test results and the post-test results of the students imply the improvement on the mastery of volleyball learning materials. The mean score of the pre-test results is 41.65 and after the learning media has been implemented the mean score of the posttest result is 89.25. The gap between the mean score of the pre-test results and the mean score of the post-test results is 47.60 points. Thus, it might be concluded that the learning media of Volleyball that has been developed by using the Adobe Flash-based TGFU method is effective and easy to understand for the students of the junior high school degree.

As having been elaborated, the product that has been resulted from the research and development initiative is the Learning Media of Volleyball that has been designed by using the Adobe Flash-based TGFU method for the junior high school students, specifically the Grade VIII students, for the learning process of Sports and Health Education in the Topic of Volleyball. Therefore, it is expected that the teachers of Sports and Health Education and also the coach of any volleyball club might benefit the learning media as an example of learning media variation. In the same time, by benefitting the learning media independently, it is expected that the students might have better understanding by means of material repetition in accordance to their desire so that such an interesting learning media might automatically improve the students' learning motivation. In turn, the students will be more enthusiastic in attending to the learning process. Furthermore, socialization on the learning media is also necessary. Through the socialization, it is expected that both the teachers and the coaches might be more facilitated in exerting their role and in implementing the learning media to all educational degrees so that the learning media might be developed in a better, more creative and more innovative manner. Last but not the least, the already certified teachers of Sports and Health Education might serve the starting point for the conduct of the future studies in the same topic.

\section{REFERENCES}

Ardiyanto, H., \& Fajaruddin, S. (2019). Tinjauan atas artikel penelitian dan pengembangan pendidikan di Jurnal Keolahragaan. Jurnal Keolahragaan, 7(1), 83-93. https://doi.org/10.21831/JK.V7I1.26394

Arikunto, S. (2016). Dasar-dasar evaluasi pendidikan (5th ed.). Jakarta: Bumi Aksara.

Badan Standar Nasional Pendidikan. (2006). Standar isi untuk satuan pendidikan dasar dan menengah: Standar kompetensi dan kompetensi dasar SMA/MA. Jakarta: Badan Standar Nasional Pendidikan.

Bangun, S. Y. (2012). Analisis tujuan materi pelajaran dan metode pembelajaran dalam pendidikan jasmani. Cerdas Sifa Pendidikan, 1(1). Retrieved from https://onlinejournal.unja.ac.id/csp/article/view/706

Dwiyogo, W. D. (2004). Konsep penelitian dan pengembangan. Malang: Pusat Kajian Kebijakan Olahraga LEMLIT UM.

Febrianta, Y., \& Sukoco, P. (2013). Upaya peningkatan pembelajaran permainan bola basket melalui metode pendekatan taktik siswa SMPN 2 Pandak Bantul. Jurnal Keolahragaan, 1(2), 186-196. https://doi.org/10.21831/JK.V1I2.2574

Gall, M. D., Gall, J. P., Borg, W. R. D., \& Gall, J. P. (2003). Educational research: An introduction (7th ed.). Boston, MA: Pearson Education Inc.

Griffin, L. L., Mitchell, S. A., \& Oslin, J. L. (1997). Teaching sports concepts and skills: A tactical games approach. Human Kinetics Publishers (UK) Ltd. 
Hanief, Y. N., \& Sugito, S. (2015). Membentuk gerak dasar pada siswa sekolah dasar melalui permainan tradisional. Jurnal SPORTIF: Jurnal Penelitian Pembelajaran, 1(1), 100-113. https://doi.org/10.29407/js_unpgri.v1i1.575

Kesumawati, S. A., Rahayu, T., \& Rahayu, S. (2018). Game model to increase fundamental movement skills in children with mild intellectual disability. International Conference on Science and Education and Technology 2018 (ISET 2018). Atlantis Press.

Kirk, D., \& MacPhail, A. (2002). Teaching games for understanding and situated learning: Rethinking the Bunker-Thorpe Model. Journal of Teaching in Physical Education, 21(2), 177-192. https://doi.org/10.1123/jtpe.21.2.177

Metzler, M. (2017). Instructional models in physical education. Routledge.

Miarso, Y. (2004). Menyemai benih teknologi pendidikan. Jakarta: Kencana.

Mitchell, S. A., Oslin, J. L., \& Griffin, L. L. (2013). Teaching sport concepts and skills: A tactical games approach for ages 7 to 18. Human Kinetics.

Presiden Republik Indonesia. Undang-Undang Republik Indonesia nomor 20 tahun 2003 tentang sistem pendidikan nasional. , Pub. L. No. 20, Undang-Undang Republik Indonesia 26 (2003).

Purwanto, P. (2005). Jejak langkah perkembangan teknologi pendidikan di Indonesia. Jakarta: Pustekkom-Depdiknas.

Rismayanthi, C. (2011). Optimalisasi pembentukan karakter dan kedisiplinansiswa sekolah dasar melalui pendidikan jasmaniolahraga dan kesehatan. Jurnal Pendidikan Jasmani Indonesia, 8(1). https://doi.org/10.21831/jpji.v8i1.3478

Sadiman, A. S. (2003). Media pendidikan: Pengertian, pengembangan dan Pemanfaatannya. Jakarta: Rajawali.

Sugiyono, S. (2015). Metode penelitian dan pengembangan. Bandung: Alfabeta.

Suprihatiningrum, J. (2013). Guru profesional: Pedoman kinerja, kualifikasi \& kompetensi guru. Yogyakarta: Ar-Ruzz Media.

Turner, A. P., \& Martinek, T. J. (1999). An investigation into teaching games for understanding: Effects on skill, knowledge, and game play. Research Quarterly for Exercise and Sport, 70(3), 286-296. https://doi.org/10.1080/02701367.1999.10608047

Viera, B. L., Fergusson, B. J., \& Monti. (2000). Bola voli tingkat pemula. Jakarta: Raja Grafindo Persada.

Werner, P., Thorpe, R., \& Bunker, D. (1996). Teaching games for understanding: Evolution of a model. Journal of Physical Education, Recreation \& Dance, 67(1), 28-33. https://doi.org/10.1080/07303084.1996.10607176 